\title{
Pancreatic Delta Cell Adenoma
}

National Cancer Institute

\section{Source}

National Cancer Institute. Pancreatic Delta Cell Adenoma. NCI Thesaurus. Code C67460.

An endocrine neoplasm arising from the delta cells of the pancreas which produce somatostatin. It does not show evidence of vascular invasion or metastasis to other anatomic sites. 